\title{
Fish Assemblage Structure Indicates Limited Restoration Progress over a Lustrum of a Severely Degraded Estuary in Southern Tamaulipas, Mexico
}

\author{
Alejandro Fierro-Cabo, Carlos E. Cintra-Buenrostro" \\ School of Earth, Environmental, and Marine Sciences, University of Texas, Rio Grande Valley, USA \\ *Corresponding Author: carlos.cintra@utrgv.edu
}

Copyright $(2017$ by authors, all rights reserved. Authors agree that this article remains permanently open access under the terms of the Creative Commons Attribution License 4.0 International License

\begin{abstract}
Today the biggest incentive to attempt the restoration and protection of estuarine systems is their widely recognized ecological and economic importance. In the reconstruction of an estuary where the original aquatic communities disappeared before the restoration interventions, the fish assemblage is an adequate source of indicators of initial recovery. Following substantial restoration efforts, this study reports on the biannual for a lustrum monitoring and assessment of a severely degraded estuary (Garrapatas) in terms of its fish assemblage using a reference estuary (Barberena) in Tamaulipas, Mexico. Twenty fishes were associated with the restoring and reference estuaries. Species composition (richness, abundance, dominance) clearly showed differences among sites. No piscivorous estuarine or marine fishes were found in Garrapatas pointing at an unbalanced and incomplete trophic chain. On the other hand, the mangrove plant community appears to have fully recovered. Water parameters were more variable in Barberena compared to the restoring sites, especially salinity, $\mathrm{DO}$, and $\mathrm{pH}$, which were also higher. Estuaries are transitional systems with inherent variation of abiotic parameters. It is proposed that this variability of abiotic parameters still missing in the restored sites, and may be key to the full recovery of biotic assemblages and ecosystem function.
\end{abstract}

Keywords Mangrove Restoration, Gulf of Mexico, Fishes, Community Structure, Community Similarity, Variability of Environmental Conditions

\section{Introduction}

Estuaries are recognized worldwide as one of the most productive ecosystems [1-3], as nursery and breeding habitats for marine organisms [4-8]), as migratory routes for either anadromous and catadromous fishes [5,9], and as permanent habitat for truly estuarine species [4,5], as well as for the critical ecosystem services they provide to humankind [10-13]. About $60 \%$ of the human population is established in estuarine watersheds [14], increasing anthropogenic pressure on estuarine resources as coastal development continues, making estuaries and other wetlands highly vulnerable to degradation and destruction $[15,16]$. Major contributors to degradation of estuaries include runoff waters and other non-point sources of pollution [17], and alteration of freshwater inflow and overall hydrological and saline regimes [18] due to filling, dredging, and impounding.

Restoration and protection of estuarine systems is promoted today at high legislative levels world-wide. For example, in the United States the Estuary Restoration Act signed in 2000 made the restoration of estuarine habitats a national priority [19]. In Europe, the Marine Strategy Framework Directive also has the restoration of estuarine and other coastal aquatic systems as a priority [20]. In Mexico, restoration of estuarine systems focuses on mangroves as they are distributed on about $66 \%$ of the $11,592 \mathrm{~km}$ of the country's coastline [21]. Over the last two decades numerous mangrove restoration efforts have been promoted by the Mexican Federal government many of which were based on environmental compensation (mitigation), and have incorporated reforestations and hydrological modifications [22].

Besides revegetation with native macrophytes like mangroves and seagrasses, the goals of estuarine restoration efforts should include the recovery of key ecosystem processes such as decomposition and nutrient dynamics [23], and the recuperation of biotic communities other than plants such as plankton, benthos, and fish [24]. Wetlands are one of the best habitats to explore the relationship between disturbance and community dynamics [25], with the notable exception of estuaries. These transitional systems with inherent variable environmental conditions can also have considerable tolerance to anthropogenic stress [26]. However, in the case of a reconstructing estuary where the aquatic communities disappeared before the initiation of restoration efforts, the fish assemblage can be considered an 
adequate source of indicators of initial recovery. Fish assemblage structure is determined by different factors varying from habitat structure, currents, depth, vegetation [27], freshwater inflow [28,5], salinity [29-31,9], temperature $[29,9]$, turbidity $[29,5,31]$, dissolved oxygen (DO) [28], type and number of refuges [32], random settlement of larvae [33,8], and competition and predation [34,8,31]. Abiotic factors (DO, salinity, temperature, etc.) have been recognized to determine coarse community structure over large spatial scales, while biotic factors refine distribution and abundances within the structure $[35,36]$. Thus, discerning the response of estuarine fishes to changes in their environment can enhance our understanding of these organisms and the potential anthropogenic effects on a degrading or restoring aquatic habitat.

The present study reports on the monitoring and assessment of a notable estuarine restoration project (Garrapatas estuary) in southern Tamaulipas, Mexico, within the territory of the industrial port of Altamira (IPA hereafter). The port's territory extends to more than 10,000 ha of coastal habitats including several shallow freshwater lagoons, salt marshes and mangrove fringed estuaries. Historically, IPA's terrestrial and aquatic ecosystems have been affected by increasing intensity of human activities. Before the 1970s livestock grazing and agriculture were widespread, and destruction of vegetation including mangroves for fuel wood and timber was common. Exploitation of other resources in the region (e.g., hydrocarbons, sea salt, artisanal fisheries) has also existed for some time before the construction of the port. With the establishment of IPA came the expansion of industrial activities. Wastewater discharges and spills from urban and industrial sources, construction of a navigation channel, and modifications to the local hydrology are added disturbances to this coastal environment. Needless to say, most of the wetlands have experienced reductions of their extension and changes in their physicochemical characteristics.

The Garrapatas estuary is located at the downstream end of a small watershed and has been affected by the disturbances mentioned above. However, the most significant disturbance to date has been the interruption of its direct connection with the Gulf of Mexico and loss of tidal influence resulting from the construction of a pipeline in 1978. The estuarine conditions were lost soon after, and it became a freshwater wetland fringed by mangrove encroached by vines, cattail and other fast growing vegetation no longer inhibited by salinity. In 1996 the estuary was designated a natural protected area by the port's administration, and by the end of 2003 as an attempt to restore the estuarine condition, a continuous seawater effluent $(620 \mathrm{l} / \mathrm{s})$ from the cooling process of a nearby thermoelectric power plant was redirected to the Garrapatas estuary [37]. The re-salinization of the estuary prompted changes in the riparian vegetation, and the freshwater aquatic communities were excluded, being gradually replaced by estuarine and marine species aided by a fish-pass installed at the mouth of the estuary.

In 2006, a multiyear assessment program was launched with the goal of documenting the response of several wetlands within IPA's territory including the Garrapatas estuary, to the exerted anthropogenic pressure, allowing for better planning and managing of current and future restoration and conservation efforts. In Mexico, decision-making on the management of coastal wetlands has been mostly based on limited physicochemical information, and lack the use of indicators of habitat health in terms of ecosystem structure and function. The multiyear assessment included the development and application of several functional and structural estuarine indicators. Such a holistic approach, to our knowledge, has not been previously attempted in the country. Here we report on the recovery of a severely degraded estuary in terms of its fish assemblage, a structural ecosystem attribute. Specifically, our objective was to evaluate how the fishes assembled following the re-salinization of the estuary as an attempt to restore its estuarine condition. We hypothesize that estuarine fishes will reassemble quickly after the re-salinization of the estuary. No quantitative data of the fish assemblages structure of the area are available, thus this study also serves as a baseline for future research on the estuarine fishes of southern Tamaulipas and central gulf coast.

\section{Materials and Methods}

\subsection{Study Sites}

The IPA is located in the southern Tamaulipas coastal plain, and its territory encompasses 17 coastal wetlands of which 15 are freshwater shallow lagoons, and two are the estuarine systems included in this study. The approach uses a reference site, the Barberena estuary, and a restoration site, the Garrapatas estuary (Figure 1). The Barberena estuary (BAR hereafter) is connected to the Gulf of Mexico trough the San Andres lagoon at its southern end. Average depth of the studied section at BAR is $1.6 \pm 0.3 \mathrm{~m}$; sediment is consolidated argillaceous (AF pers. obs.) and its riparian vegetation is dominated by black (Avicennia germinans (Linnaeus, 1759)) and white (Laguncularia racemosa (Gaertner, 1788), with sparse buttonwood (Conocarpus erectus Linnaeus, 1753) mangroves. Average \pm SE water temperature is $28.3 \pm 1.0^{\circ} \mathrm{C}$ ranging from $26.9-32.4^{\circ} \mathrm{C}$; and salinity is $33.6 \pm 3.1 \mathrm{~g} / \mathrm{l}$, range $=3.9-53.0 \mathrm{~g} / \mathrm{l}$. This estuary is considered a reference site as its hydrologic and saline regimes have not been modified as in the case of the Garrapatas estuary. 


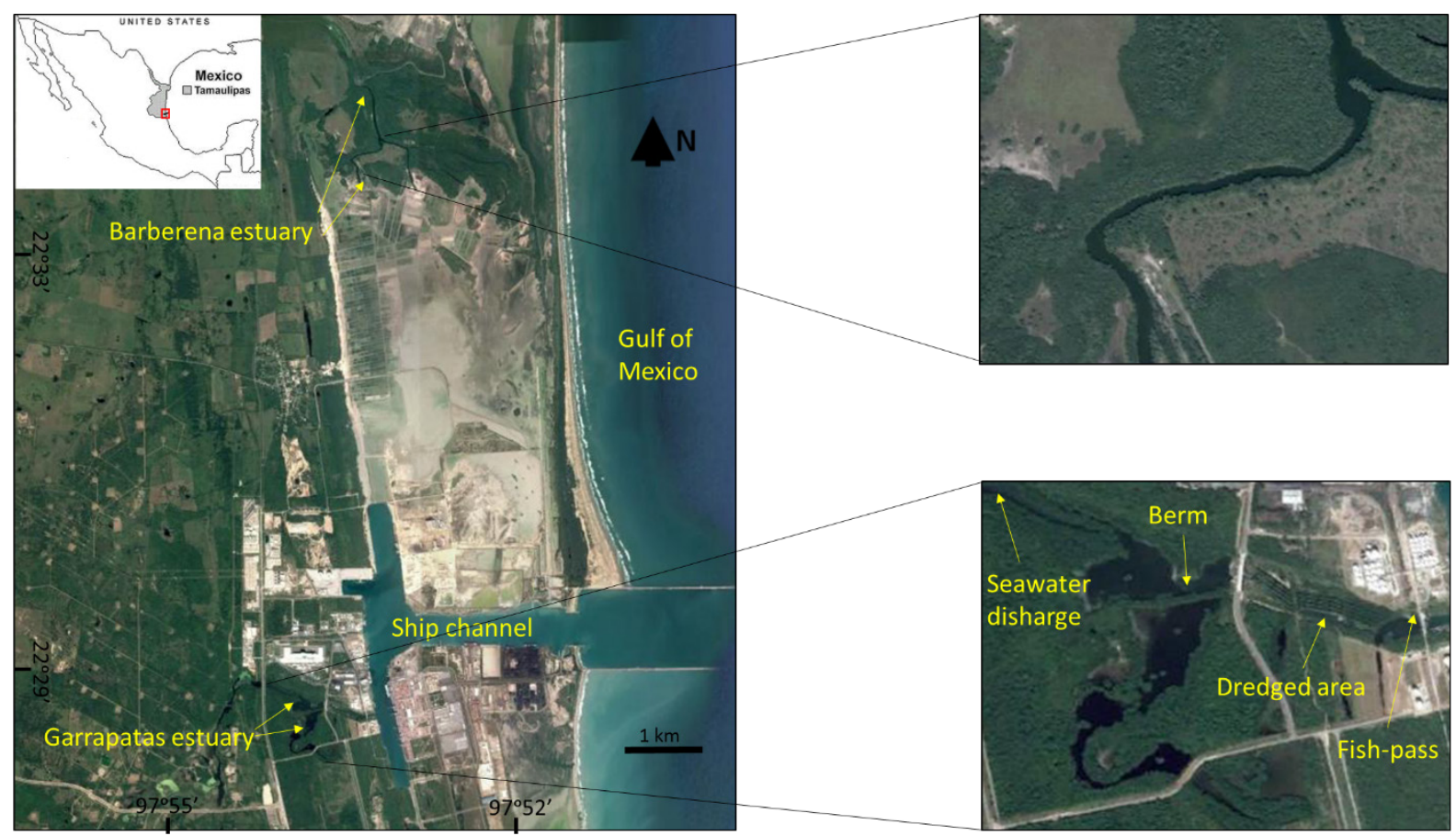

Figure 1. Study sites in southern Tamaulipas, Mexico. The Garrapatas estuary in its two sections (north and south referred respectively as GEN and GES in the text) separated by an old berm, and the nearby Barberena estuary representing reference conditions. Modified from [38]

The Garrapatas estuary is traversed by an old berm (Figure 1) that was a continuation of a previously existing dirt road going to the beach. This berm has a single narrow opening ( $4 \mathrm{~m}$ wide) and effectively separates the estuary in two sections, the north section (GEN) and the south section (GES). These sections present dissimilar conditions and recovery states, and thus were considered as different systems for this study. Average \pm SE depth for GEN and GES are $1.6 \pm 0.2$, and $1.7 \pm 0.1 \mathrm{~m}$, respectively. Red mangrove (Rhizophora mangle Linnaeus, 1753) dominates the riparian vegetation in both sections of the estuary, with $C$. erectus in short sections of the margins, and isolated individuals of $A$. germinans and $L$. racemosa. The sediment in GEN is similar to BAR but less consolidated, while GES has an unconsolidated organogenic sediment (AF pers. obs.). Over the study period (2006-2010), GEN had an average \pm SE water temperature of $30.0 \pm 0.3^{\circ} \mathrm{C}$, range $=26.9-32.7^{\circ} \mathrm{C}$; and an average salinity of $19.8 \pm 2.3 \mathrm{~g} / \mathrm{l}$, range $=7.2-46.3 \mathrm{~g} / \mathrm{l}$ while at GES average temperature was $29.1 \pm 0.5^{\circ} \mathrm{C}$ with a range of $25.2-34.4^{\circ} \mathrm{C}$; and salinity was $13.8 \pm 2.1 \mathrm{~g} / 1$, range $=$ $1.4-36.1 \mathrm{~g} / 1$.

\subsection{Sampling and Experimental Design}

Based on the results of a one-year preliminary assessment performed quarterly (data not shown), it was determined to sample all sites biannually thereafter, that is under typical dry season conditions (May-June), and under typical wet seasons conditions (September-October) of the region for five consecutive years (2006-2010). This sampling schedule ensured a representation of the typical conditions of both dry and rainy seasons, accounting for the anticipated seasonal variability in the fish assemblages composition. Unless otherwise noted, the sampling design consisted of three replicates or sampling stations per site for both fish assemblage metrics and water parameters.

The fish assemblages were sampled using an experimental gillnet consisting of six $10 \mathrm{~m}$ wide panels, two of each of the following mesh sizes: 38,51 and $64 \mathrm{~mm}$, distributed in that order. The gillnet was deployed for 30 minutes across the estuary in each sampling station. Additionally, and in order to capture smaller individuals, a cast net (1.6 m radius, 19 $\mathrm{mm}$ mesh) was deployed five times around each sampling station. All individuals were identified to species level (one species was identified at the genus level, Poecilia sp.), and then released in place.

The following water parameters were measured in situ at a depth of $0.5 \mathrm{~m}: \mathrm{DO}( \pm 0.01 \mathrm{mg} / \mathrm{l})$, temperature $\left( \pm 0.1^{\circ} \mathrm{C}\right)$ and salinity $( \pm 0.01 \mathrm{~g} / \mathrm{l})$ with a datasonde (Hach HQ40d), $\mathrm{pH}( \pm$ 0.1 ) with a WP pH Testr 2 DJ (Oakton Instruments), and transparency with a secchi disk. One composite sample/site/sampling date made of 0.51 from the three replicates at each site was analyzed for total suspended solids (TSS; standard method, $\pm 0.01 \mathrm{mg} / \mathrm{l}$ ).

\subsection{Statistical Analyses}

Fish assemblages were compared across sites and years using a two-way Analysis of Similarity (ANOSIM) in Primer v6 [39]. Cluster analysis plots based upon Bray-Curtis similarities (group averaged) were used as an additional tool for identifying natural groups in fish assemblages. All data were fourth-root transformed in order to down-weight the contributions of highly abundant species and thereby 
allowing mid-range species to also influence assemblage similarity calculations [40]. A SIMPROF test was performed in every cluster analysis to identify genuine groupings, which were also identified via Principal Component Analysis (PCA) using environmental variables. Environmental data were normalized sensu Clarke and Warwick [40]. Correlations between the first two PC's and environmental data were analyzed with Spearman rank coefficients. Similarity Percentages (SIMPER) were calculated to determine what species contributed to dissimilarities among sites and years. Species Richness, Shannon's Diversity ( $\left.\mathrm{H}^{\prime}\left(\log _{10}\right)\right)$, and water parameters measured in situ were compared among sites and years using ANOVA. Because of their lower replication TSS data were compared graphically with their descriptive statistics (i.e., mean $\pm \mathrm{SE}$ ), hence no further statistical testing was performed because it was not considered robust.

Fish abundance was compared among sites and seasons with a two-way ANOVA, but there were no significant differences between seasons $\left(\mathrm{F}_{0.05(1,71)}=3.24, \mathrm{p}=0.07\right)$. Thus, data of the two seasons were pooled and analyzed using fish abundance per year and per site with a two-way ANOVA. Species richness and diversity data were treated similarly; Q-Q plots and Kolmogorov-Smirnov test were used to verify normality while homoscedasticity was corroborated with Levene's test in order to comply with the ANOVA's assumptions [41,42]. In case an assumption was violated the necessary data transformations to meet it are mentioned in the results. Tukey's test $[41,42]$ was used $a$ posteriori to indicate what sites and/or years caused any of the significant differences. All parametric statistics were performed with SPSS v22.

\section{Results}

Over the lustrum monitoring period a total of 20 fish species were found associated with the restoring and/or reference estuaries: finescale menhaden (Brevoortia gunteri), striped mullet (Mugil cephalus), white mullet (Mugil curema) and blue tilapia (Oreochromis aureus) occurred in all estuaries, 11 species occurred only in BAR, while three only in GES, there were no species unique to GEN (Table 1). The three most abundant fishes were B. gunteri $(43.8 \%), O$. aureus $(33.4 \%)$, and M. cephalus $(8.1 \%)$.

Table 1. Fish species found in the study sites during 2006-2010. Species with high trophic level are indicated as piscivorous. Barberena estuary $=$ BAR, Garrapatas estuary north $=$ GEN, and Garrapatas estuary south $=$ GES

\begin{tabular}{|c|c|c|}
\hline Species & Site & Piscivorous \\
\hline Archosargus probatocephalus (Walbaum, 1792) & BAR & \\
\hline Ariopsis felis (Linnaeus, 1766) & BAR & $\mathrm{X}$ \\
\hline Astyanax mexicanus (de Filippi, 1853) & GES & \\
\hline Brevoortia gunteri Hildebrand, 1948 & BAR, GEN, GES & \\
\hline Brevoortia patronus Goode, 1878 & BAR & \\
\hline Caranx hippos (Linnaeus, 1766) & BAR & $\mathrm{X}$ \\
\hline Centropomus undecimalis (Bloch, 1792) & BAR & $\mathrm{X}$ \\
\hline Cyprinodon variegatus Lacépède, 1803 & GEN, GES & \\
\hline Dormitator maculatus (Bloch, 1792) & GES & \\
\hline Eleotris pisonis (Gmelin, 1789) & BAR & $\mathrm{X}$ \\
\hline Elops saurus Linnaeus, 1766 & BAR & $\mathrm{X}$ \\
\hline Eucinostomus argenteus Baird and Girard, 1855 & BAR & \\
\hline Eugerres mexicanus (Steindachner, 1863) & BAR & $\mathrm{X}$ \\
\hline Herichthys cyanoguttatus Baird and Girard, 1854 & GEN, GES & \\
\hline Megalops atlanticus Valenciennes, 1847 & BAR & $\mathrm{X}$ \\
\hline Micropogonias undulatus (Linnaeus, 1766) & BAR & $\mathrm{X}$ \\
\hline Mugil cephalus Linnaeus, 1758 & BAR, GEN, GES & \\
\hline Mugil curema Valenciennes, 1836 & BAR, GEN, GES & \\
\hline Oreochromis aureus (Steindachner, 1864) & BAR, GEN, GES & \\
\hline Poecilia sp. & GES & \\
\hline
\end{tabular}




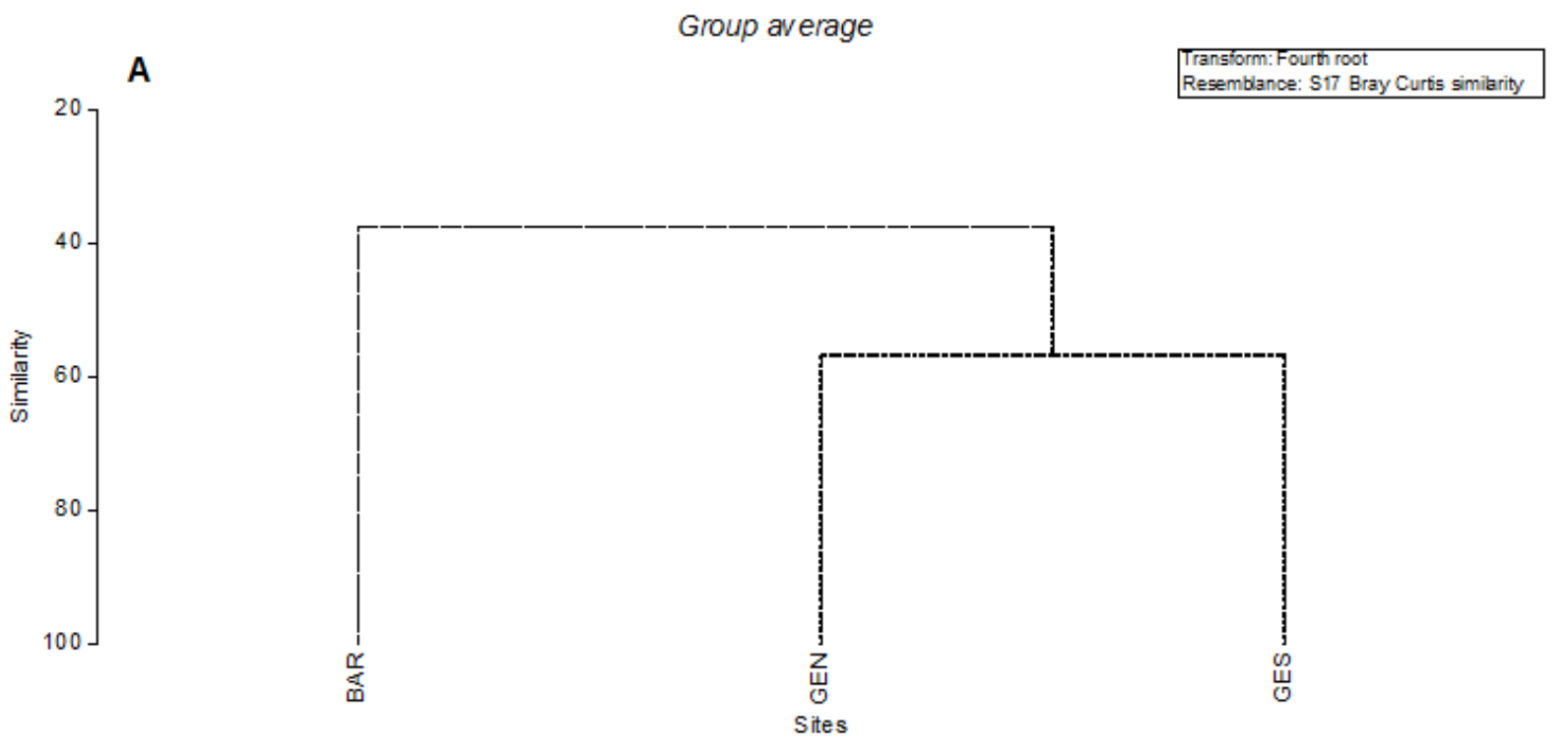

Group average

B
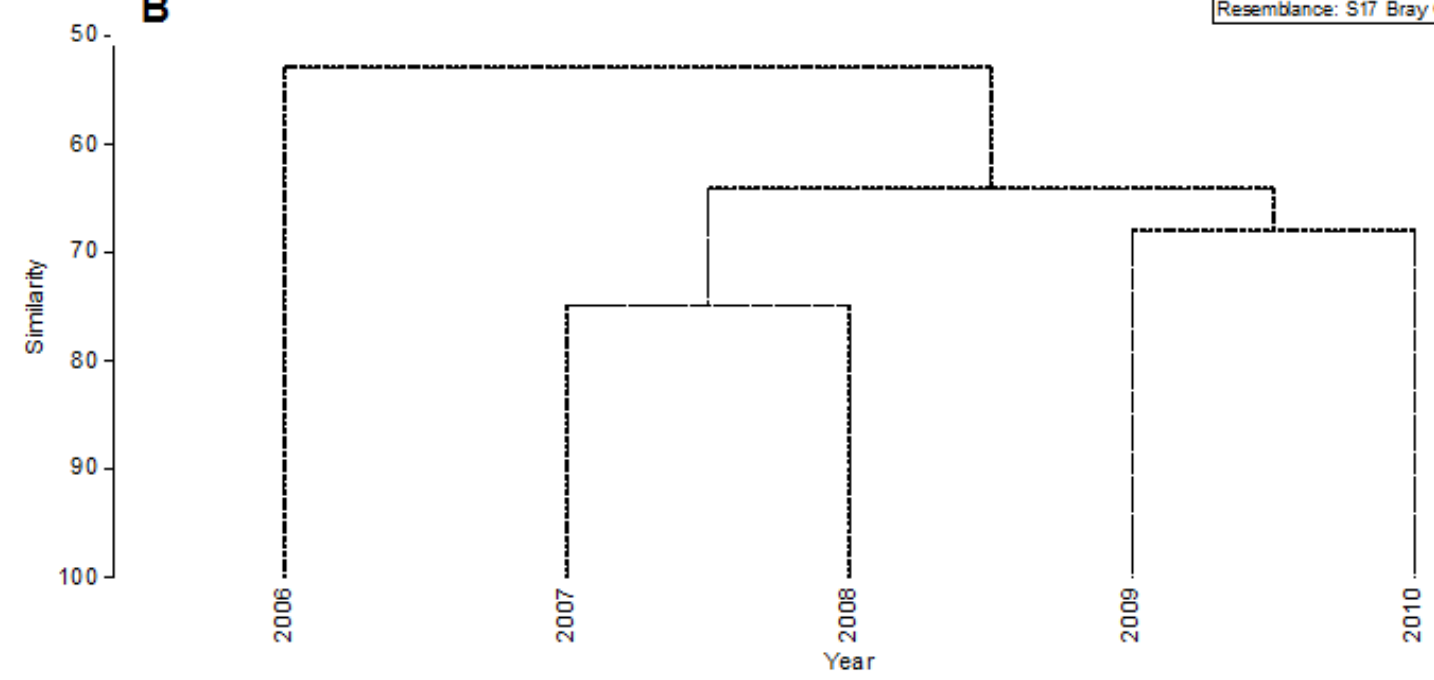

Figure 2. Percentage similarity of fishes by cluster analysis including SIMPROF test: A) among sites; and B) among years (2006 to 2010). Dotted lines indicate no significant differences in groupings $(\mathrm{p}>0.05)$; BAR $=$ Barberena estuary, GEN $=$ Garrapatas estuary north, and GES $=$ Garrapatas estuary south

Similarity among sites varied from $\sim 42-57 \%$, two groups of fish assemblages are clearly separated by cluster analysis (BAR and the two restoration sites: GEN and GES) (Figure 2A), but this natural clustering was not significantly different as per the SIMPROF test $(\pi=4.45, \mathrm{p}=0.06$ at 37.4$)$. Similarities among years were higher $(\sim 48-75 \%)$ and, the visual effect depicted by the dendrogram shows a clear separation of 2006 from the other years, which cluster in two groups: 2007 and 2008, and 2009 and 2010 (Figure 2B), but again the groupings were not significantly different $(\pi=1.15$, $\mathrm{p}=0.97$ at 52.8). The two-way ANOSIM yielded no significant differences among years $(\mathrm{R}=0.11, \mathrm{p}=0.281)$ neither among sites $(R=-0.02, p=0.479)$ supporting the

\section{SIMPROF tests.}

Based on the SIMPROF results, a PCA was performed only among sites, which had the outcome in the vicinity of significance $(\mathrm{p} \sim 0.05)$. Two components explained $61.6 \%$ the variation among sites, all parameters were inversely related along $\mathrm{PC} 1$, and salinity was also inversely related along PC2 (Figure 3). Considering their vector length, DO and secchi depth best correlated with PC1 $(r=-0.76$ and 0.35 , respectively), and salinity best correlated with PC2 ( $\mathrm{r}=$ - 0.85). These parameters account for most of the observed variation, however secchi depth contributes less than half of either DO or salinity (Figure 3). 


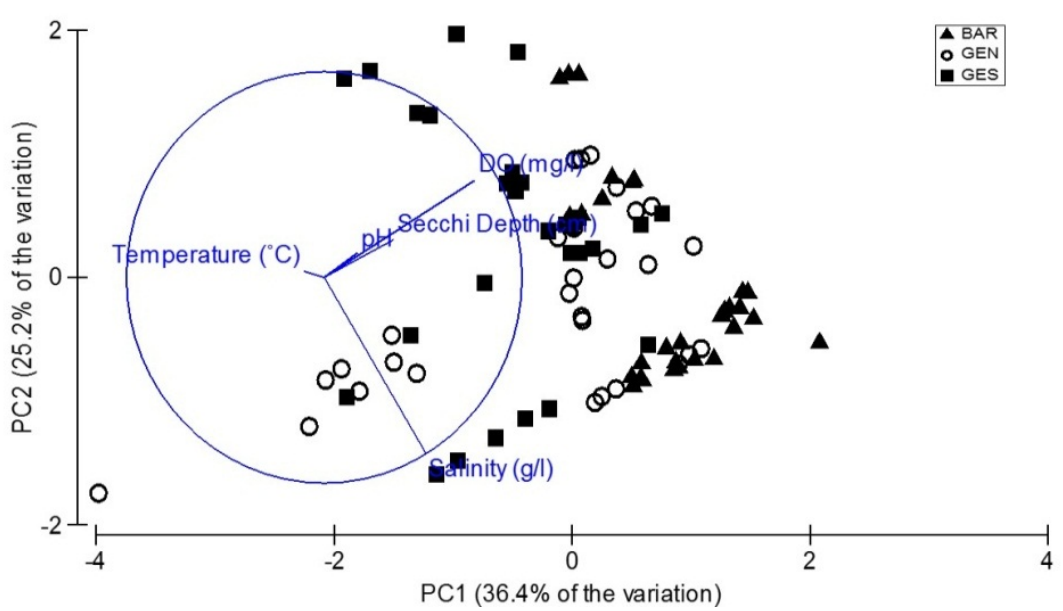

Figure 3. Principal component analysis (PCA) of dissolved oxygen $(\mathrm{DO}, \mathrm{mg} / \mathrm{l})$, temperature $\left({ }^{\circ} \mathrm{C}\right)$, salinity $(\mathrm{g} / \mathrm{l})$, secchi depth $(\mathrm{cm})$, and $\mathrm{pH}$ found over the three study sites. The vector lengths represent the importance of that variable's along the two plotted axes in relation to all possible PC's, while distance relative to outer circle is an indication of how much variation is explained by each vector. Site labels as in Figure 2

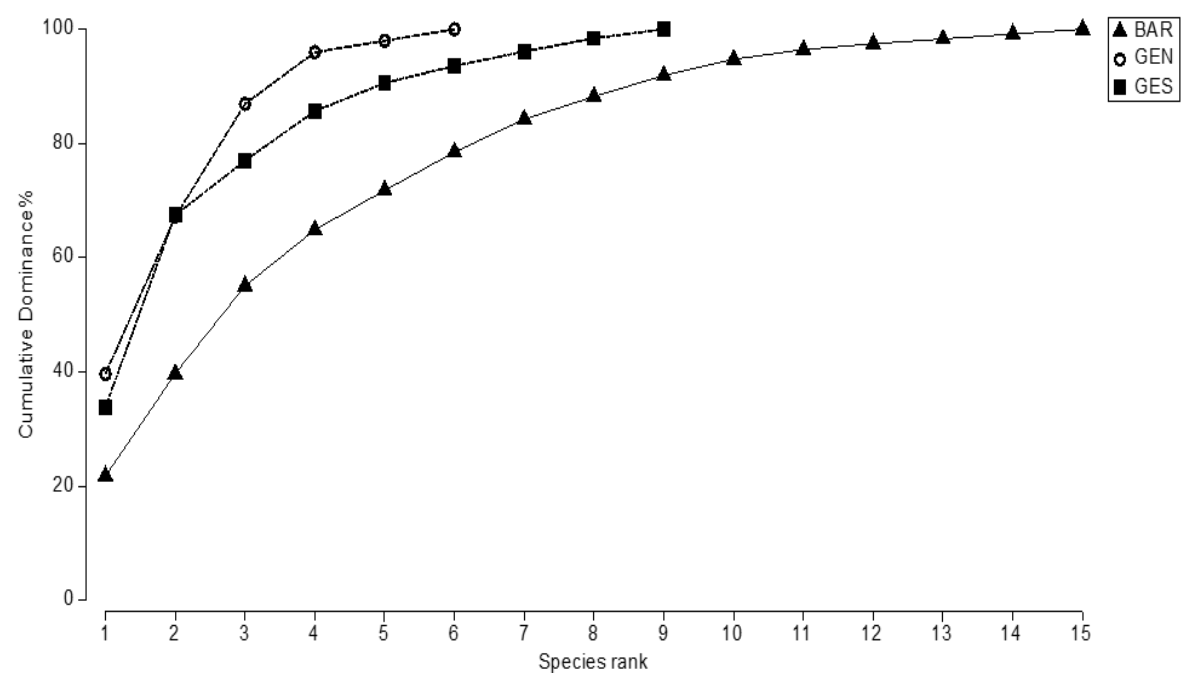

Figure 4. Cumulative dominance (\%) of fish species by their abundance ranked in order of dominance. Site labels as in Figure 2. Note GES sample overlaps with GEN for the second most abundant species

From the SIMPER analysis, the groups were $~ 56-72 \%$ dissimilar with six to 11 fishes contributing to $90 \%$ of such differences. The four most abundant species among sites tended to explain a high percentage of the dissimilarities detected, particularly $O$. aureus and $B$. gunteri with values ranging from 9.3-38.5 and 14.7-23.4\%, respectively. For the years, dissimilarities ranged from $31.7-79.0 \%$ with five to 12 fishes contributing $90 \%$. In general, 2006 had the least fishes to account for the observed dissimilarities than the rest, which mostly needed ten species to yield such percentage. Once more, for the majority of the comparisons either two or three of the commonly found species in all sites were responsible for the higher contributions, in particular $B$. gunteri, O. aureus and M. cephalus.

Differences in species dominance were observed among estuaries. For example, in BAR seven species accounted for $\geq 80 \%$ of total abundance, while four species in GES and three fishes in GEN represented this portion of their fish assemblage (Figure 4). The three most abundant fishes at each site were B. gunteri $>M$. cephalus $>$ Ariopsis felis for
BAR; B. gunteri $>O$. aureus $>$ M. cephalus for GEN; and $O$. aureus $>$ B. gunteri $>$ Poecilia sp. for GES.

A two-way ANOVA with abundance data $\log _{10}+1$ transformed to meet homoscedasticity, indicated no significant differences among years $\left(\mathrm{F}_{0.05}(4,71)=1.16, \mathrm{p}=\right.$ 0.336), but abundances were different among sites $\left(\mathrm{F}_{0.05}(2,71)\right.$ $=12.96, p=0.0001)$. There was no interaction effect $\left(F_{0.05}\right.$ $(7,71)=1.84, p=0.097)$. The differences among sites were caused by GES (Figure 5A) as per the Tukey test. Total abundance in GES was more than three times higher than in the other sites for all years combined, such value was largely dominated by one or two species as mentioned above.

On average $( \pm \mathrm{SE})$ there were $5.6 \pm 0.77$ species, and no significant differences among years $\left(\mathrm{F}_{0.05}(4,14)=0.53, \mathrm{p}=\right.$ 0.714). Species richness among sites was highest in BAR and lowest in GEN (Figure 5B) by a three-fold factor for all years combined; this difference was significant $\left(\mathrm{F}_{0.05(2,14)}=\right.$ $17.06, p=0.0001)$.

Average $( \pm$ SE) diversity index value was $1.4 \pm 0.15$ without significant differences among years $\left(\mathrm{F}_{0.05}(4,14)=\right.$ 
$0.74, p=0.587)$. Among sites, BAR was again the site with greater diversity while GEN continued to show the lowest values (Figure $5 \mathrm{C}$ ). This difference was also detected by the ANOVA $\left(\mathrm{F}_{0.05}(2,14)=9.89, \mathrm{p}=0.003\right)$, and the Tukey test confirmed that BAR caused the observed differences.
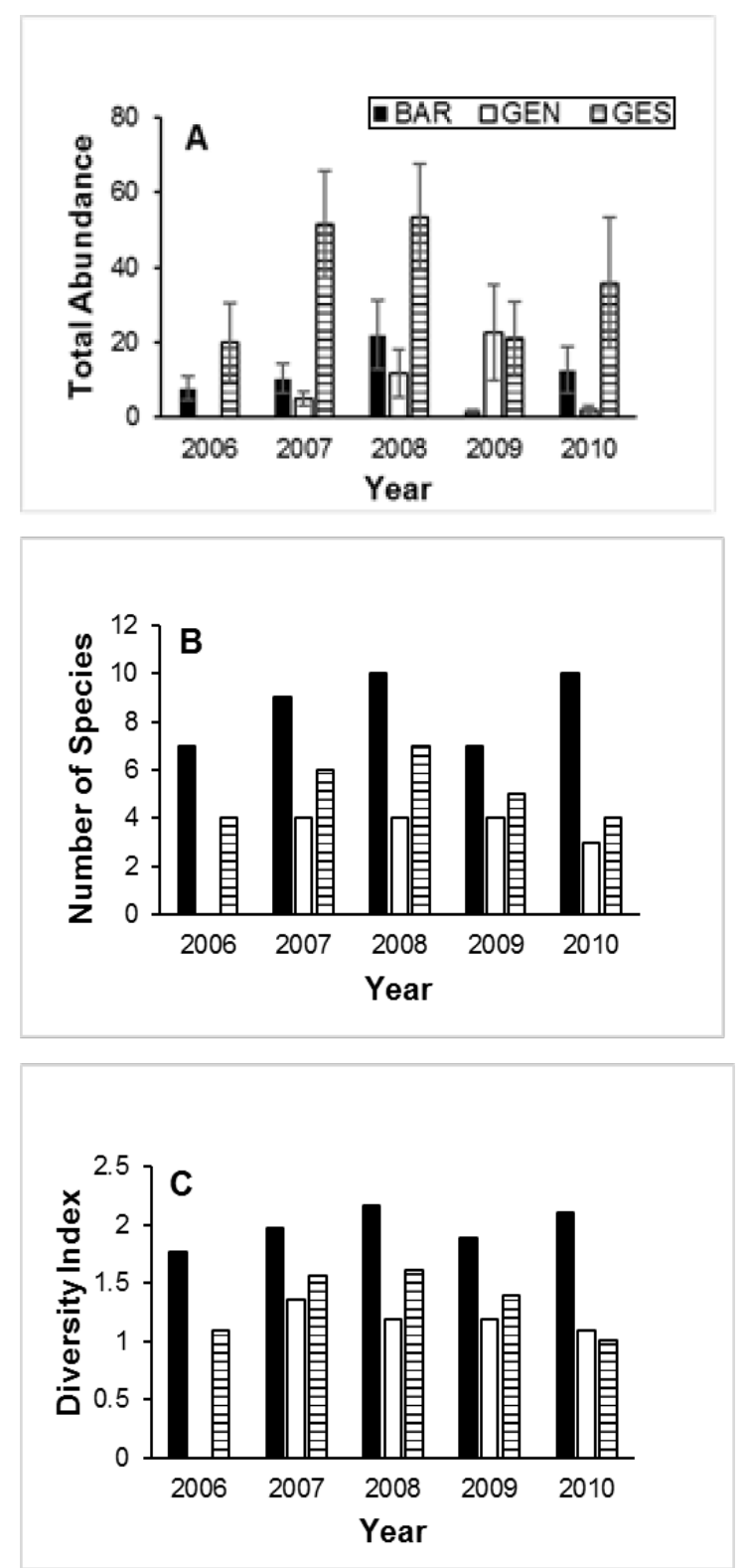

Figure 5. Fish assemblage metrics over time in the study sites. A) Total abundance (average \pm standard error, bars) of fishes; B) species richness; and C) Shannon diversity index. No bars are reported in "B" and "C" because illustrated values resulted from calculated indices. Sample size $=6$ replicates/site/year. Site labels as in Figure 2
Average $( \pm \mathrm{SE}) \mathrm{DO}$ was $3.9 \pm 0.27 \mathrm{mg} / \mathrm{l}$, being greatest in 2008 and lowest in 2006, however there are no significant differences among years $\left(\mathrm{F}_{0.05(4,89)}=0.66, \mathrm{p}=0.623\right)$. Sites were significantly different $\left(\mathrm{F}_{0.05(2,89)}=21.69, \mathrm{p}=0.0001\right)$ with BAR showing the highest and GES the lowest values (Figure 6A); the Tukey test attributed the difference to BAR.

Temperature averaged $( \pm \mathrm{SE}) 29.1 \pm 0.4^{\circ} \mathrm{C}$, and tended to be higher in 2008 and 2009, and lower in 2007. Temperature data were $\log _{10}$ transformed to achieve normality and indicated significant differences among years $\left(\mathrm{F}_{0.05(4,89)}=\right.$ $8.32, \mathrm{p}=0.0001) ; 2009$ was different from all other years except 2007, the remaining years showed either one or two differences among each other as per the Tukey test. In contrast there were no significant differences among sites $(\mathrm{F}$ $\left.0.05_{(2,89)}=1.67, \mathrm{p}=0.195\right)$ (Figure 6B).

Salinity averaged $( \pm$ SE) $22.4 \pm 1.71 \mathrm{~g} / \mathrm{l}$, and differences among years were significant $\left(\mathrm{F}_{0.05(4,89)}=15.58, \mathrm{p}=0.0001\right)$, not surprisingly 2006 was responsible for the observed difference, which was also attributed to 2009 as per the Tukey test. There were also significant differences in salinity among sites $\left(\mathrm{F}_{0.05}(2,89)=15.51, \mathrm{p}=0.0001\right)$, with BAR showing the largest and GES the lowest values (Figure 6C) with about $20 \mathrm{~g} / 1$ difference (all years combined) between these sites. The Tukey test attributed the observed difference to BAR.

Water transparency measured by depth of a secchi disk averaged $( \pm \mathrm{SE}) 55.9 \pm 2.9 \mathrm{~cm}$, and was not significantly different among years $\left(\overline{\mathrm{F}}_{0.05}(4,89)=1.21, \mathrm{p}=0.310\right)$. Neither were differences among sites $\left(\mathrm{F}_{0.05(2,89)}=2.03, \mathrm{p}=0.138\right)$, even when GES showed the clearest and BAR the least clear water, which tended to be more evident for GES on the later years (Figure 6D).

Lastly, $\mathrm{pH}$ averaged $( \pm \mathrm{SE}) 8.2 \pm 0.05$; with significant differences among years $\left(\mathrm{F}_{0.05}(4,89)=11.47, \mathrm{p}=0.0001\right)$, the differences detected by the Tukey test were attributed to either two or three more years, for example 2008 and 2009 were not different from one another but yielded differences with 2010 (only 2009) or 2006 and 2007 (only 2008). Among sites, BAR showed higher $\mathrm{pH}$ than the two restoration sites (Figure 6E), these values were significantly different $\left(\mathrm{F}_{0.05}(2,89)=8.33, \mathrm{p}=0.0001\right)$; BAR was responsible for the differences as per the Tukey test.

The highest and lowest TSS concentrations occurred in the last two years, respectively. This water parameter was measured in composite samples - as mentioned before - and tended to be higher in BAR compared to the restoration sites (Figure 6F), in accordance to the water transparency trends observed. 

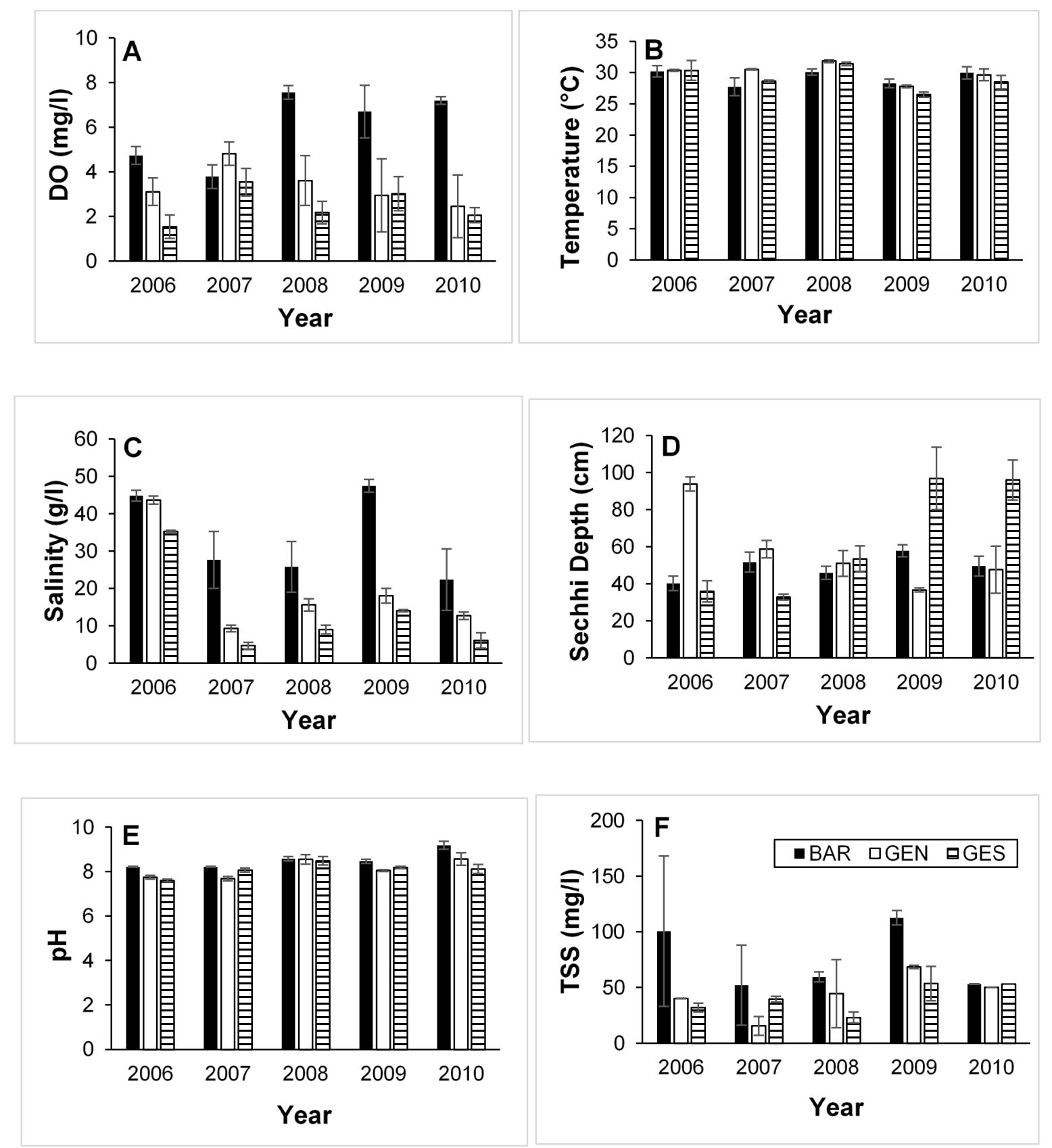

Figure 6. Water parameters over time at the study sites (average \pm standard error, bars). A) Dissolved oxygen (DO); B) water temperature; C) salinity; D) secchi depth; E) pH; and F) total suspended solids (TSS). Sample size and labels as in Figure 5, except for TSS were composite samples were used (see text for details)

\section{Discussion}

The Garrapatas estuary was the object of costly interventions to restore its long-lost estuarine conditions and improve the quality of such habitat. It is one of the most relevant examples of private investment in estuarine restoration in Mexico. The main interventions included the redirection of the seawater effluent from the power plant $(\sim 3$ $\mathrm{km}$ detour to reach the estuary), the construction and maintenance of a fish-pass, the dredging of the heavily silted lower end of the estuary followed by mangrove revegetation of the resulting spoil islands (Figure 7). Mangrove reforestation in other parts of the estuary was initiated and abandoned within the second year following re-salinization due to abundant natural propagules recruitment. Surviving old-growth mangrove stands recovered quickly and remarkably (only qualitative assessments were done), but other components of the ecosystem have not completely recovered, including the fish assemblages. 

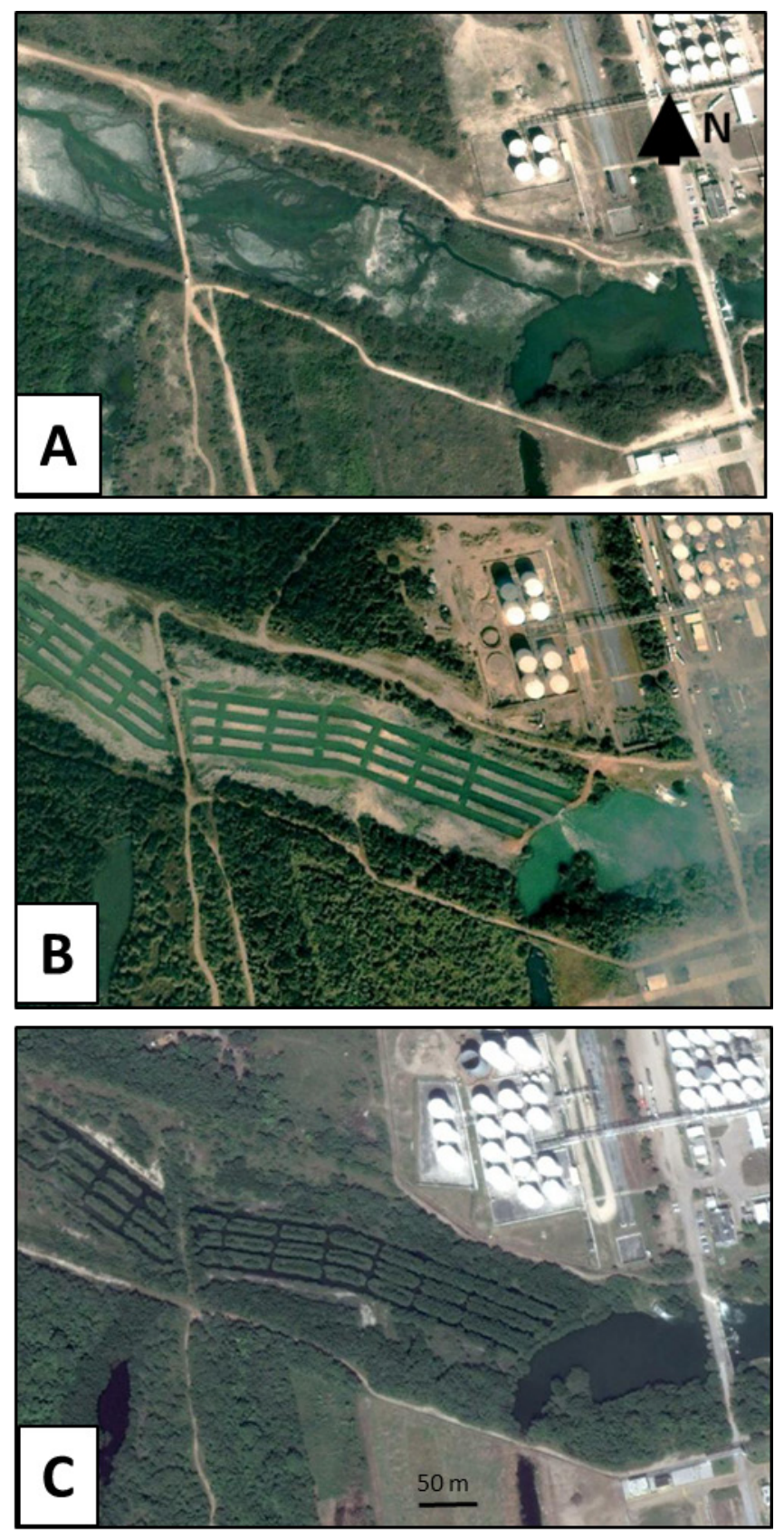

Figure 7. Dredged area at the lower part of the Garrapatas estuary (see Figure 1 for location). A) Before dredging (2006); B) after dredging several deeper channels and building spoil islands (2007); and C) mangrove-revegetated spoil islands showing nearly closed canopy (2016). Adapted from [38]

The species composition clearly shows that the two sections of the restoring Garrapatas estuary still very different to the reference site (BAR) in terms of the fish assemblages. In addition to lower specific richness, the majority of fishes found in both sections of the Garrapatas estuary are considered "legacy" species; being freshwater or oligohaline species and occurring before the re-salinization. Six legacy species were recorded including the invasive $O$. aureus, whereas only three estuarine fishes have returned including the two mullet species ( $M$. cephalus and $M$. curema) and B. gunteri. It is noteworthy that no piscivorous estuarine or marine fishes were found, pointing at an unbalanced and incomplete trophic chain in this ecosystem.
Similarly, in small Portuguese estuaries only one or two piscivorous fishes were found in the two most anthropogenically affected estuaries and only half of all species, compared to well preserved sites [43]. Total abundance was consistently much higher in GES. Other than the invasive $O$. aureus, the most abundant species in both sections of the Garrapatas was B. gunteri, a planktivorous species. Higher primary productivity (i.e., higher chlorophyll "a" concentrations, not shown), and the lack of predatory fishes may explain such abundance. High abundances caused by opportunistic fishes frequently indicate a disturbed community [24].

Higher diversity and species richness were consistently 
observed in BAR over the monitoring lustrum of fish assemblages, compared to both sections of the Garrapatas. The majority of fishes do not use estuarine habitats for reproduction (i.e., maturation and spawning), but as feeding grounds [44]. Utilization of food resources by estuarine or estuary-user fishes is dictated by the large variation of abiotic parameters which, in turn, condition food supply and competing species $[44,6,8]$, and results in higher diversity overall. As discussed below, water parameters are more variable in BAR compared to either site of the Garrapatas estuary, in particular salinity and TSS, which may partially explain the observed differences in diversity. Moreover, the two-way ANOVA showed no differences in total fishes abundance among years, but were observed among sites, with the more degraded section (GES) being responsible for the difference (Figure 5A). In this case, GES showed greater total abundances (1,090 individuals) than the reference site (326 individuals) or the less degraded section (GEN). The species driving these abundances (O. aureus and B. gunteri), have a low trophic level and one is considered invasive. Additionally, species richness is a decreasing function of abundance under the log-series distribution, which empirically - along with the log-normal - are the best approximates of relative abundances [45].

Although it might seem counterintuitive, the lack of significant differences in fish assemblages similarity among sites should not be that surprising given the recorded values (similarities $\sim 42-57 \%$ ), near $50 \%$ chance of being either similar or dissimilar which can be misleading. Even though similarities among years improved $(\sim 48-75 \%)$ the lack of significance remained. The observed separation of 2006 from all other years was expected given that was the first year of sampling and only three years after rehabilitation of GEN/GES, the following years (2007-2010) tend to clump together (Figure 2B). Smaller differences in fish assemblages among years than among sites of various ecological status have also been reported for Oregon streams [46,47], and streams of the mid-Atlantic region [48]. The relatively high variability observed among replicates, with species richness ranging from $6-15$ or $10-14$ and their abundances from 248-1,090 or 166-523 among sites and years, respectively might account for the lack of significant differences in similarity by allowing migration of the individuals among and outside the sites. Indeed, the swimming ability and associated feeding performance enable some species to explore different niches, shaping and reshaping fish assemblages in the same area [49]. Thus, the high turnover rate of species may be artifacts of the small scale habitats studied; something that has been observed on small patches of reef structures [33], small replicate reefs or reef-like structures were species composition does not reach equilibrium [27].

Another factor contributing to the lack of significant differences in similarities is the number of species, which was not significantly different among years, but was among sites. As expected the reference site had the highest richness (15 species), which is $\sim 2.5$ times the lowest value observed in GEN (6 species) (Figures 4 and 5B). Species number from BAR compares to the monthly average observed in the Scheldt estuary, which had four species dominating $90 \%$ of the assemblage [9]. In the studied sites, three fishes $(B$. gunteri, O. aureus, and M. cephalus), accounted for $85.3 \%$ of the assemblages.

The structure of estuarine fish assemblages is primarily the result of abiotic factors and their gradients, as well as the result of ontogenic migrations [36]. At smaller scales, species interactions (foraging, competition, predator avoidance) also play a structuring role. The comparison of environmental parameters among sites yielded DO, salinity and $\mathrm{pH}$ as significantly different. The interannual comparison of these parameters yielded significant differences in temperature, salinity and $\mathrm{pH}$, which may not have any ecological relevance in the present study and hence are not discussed any further. It has been established that on a temporal scale temperature, and on a spatial scale salinity and turbidity are the best predictors for estuarine species abundance and spatiotemporal community structure [9].

Dissolved oxygen appeared as a driving factor, being lower in the restored sites over the monitoring period. The lack of tidal water movement and seasonal flushing of accumulated organic matter in the bottom may explain this condition. Indeed, readings below $2 \mathrm{mg} / \mathrm{l}$ were recorded 0.2 $\mathrm{m}$ above the bottom in both GEN and GES for most of the sampling events (not shown). Similar conditions (i.e., DO < $2 \mathrm{mg} / \mathrm{l}$ near the bottom) resulted in sharp reductions of fish abundances and species richness in an estuarine system of Florida [28].

As revealed by the PCA, salinity is one of the main factors explaining the variance of the first two components. This result is in correspondence with the main conclusion of a study looking at the effects of various gradients from marine to estuarine to river environments, where salinity was identified as the most important determinant of fish assemblages [36]. The restored sites recorded the lowest salinities being less in GES (Figure 6C), where O. aureus was the numerically dominant species, while at GEN it occupied the second place in abundance and was not even among the top five abundant fishes in BAR. Furthermore, salinity requirements of a species can vary through ontogeny, for example, juvenile $M$. cephalus showed a preference for fresh or oligohaline waters, while adults preferred euhaline waters [50]. Salinity is one of the prevailing abiotic factors contributing to differences in species richness, diversity, evenness and biomass in the Elbe estuary, Germany [51]; while in the USA at Fort Bayou, Mississippi, turbidity and salinity were positively related to marine fishes abundances with the opposite relation for freshwater fishes [29]. In the Pueblo Viejo lagoon, another estuarine system located about $30 \mathrm{~km}$ south of the Garrapatas estuary, specimens collected with seine net of $B$. gunteri were associated with sites lacking vegetation and higher salinities, while its congeneric B. patronus preferred lower salinity and dense beds of wigeongrass (Ruppia marina Linnaeus, 1753); resulting in higher abundances of $B$. gunteri during dry seasons [6]. 
Although both taxa are estuarine dependent species for nursery and feeding taking advantage of the warm temperature and food abundance [6], this pattern is not supported by our results, first because there were no significant differences between seasons (dry vs. wet), second because of the smaller almost negligible $(0.12 \%)$ abundances of B. patronus (perhaps differences in sampling method exacerbate this difference), and lastly salinity was inversely related to fishes similarity with greater effects at the restored sites (Figure 3).

A factor that was not detected as significantly different in the comparison of environmental parameters, but played a role in the observed variation from the PCA is turbidity. Survival of juvenile estuarine fishes can be enhanced by high turbidity [29,5,31]. The reference site (BAR) had continuously higher turbidities (as per secchi depth and TSS), which may partially contribute to its higher richness and diversity. Turbidity increased with heavy rainfall and varied seasonally but no effect on the temporal variation in fish assemblage structure was detected in the Koycegiz lagoon-estuary, Turkey [31]. In general, BAR showed the highest TSS concentrations among the three sites (Figure 6F), this reference site was also dominated (abundance-wise) by B. gunteri, which might have benefited of the local turbidity to avoid potential predators [5]. Furthermore, the second dominant species M. cephalus is also known to inhabit turbid environments, particularly in the early stages of its ontogeny [31] given that there is more time and energy spent locating and consuming prey under turbid than clearer waters [52]. However, because no attempt to characterize predator-prey interactions was taken in the present study, and also because BAR was the only site where piscivorous fishes were recorded (Table 1), the necessary approach targeting this and other biotic interactions is called for before further speculation or discussion. The overall lower turbidity observed in both sections of the Garrapatas estuary is a consequence, at least partially, of the lack of tidal currents which may never be restored.

\section{Conclusions}

Estuarine habitats are transitional systems with natural inherent variation of abiotic parameters, which probably represents the biggest challenge in estuarine restoration. Rehabilitating the variation of abiotic conditions in a restoring estuary might well be the key to approach full recovery in both ecosystem structure as indicated by biotic assemblages, and ecosystem function as indicated by critical ecosystem processes. In the Garrapatas estuary, reestablishing water salinity was believed to be the most needed intervention for restoring the ecosystem. The mangrove assemblage responded positively to this intervention, old-growth mangrove stands fully recovered in a short time, and propagules recruitment resumed abundantly. In other words, passive restoration of the plant assemblage was successful and rapid after the initial intervention.
However, aquatic assemblages including the fish have not recovered eight years after re-salinization. This intervention as well as the other efforts such as dredging and a fish-pass, did not reestablish the inherent variation of abiotic conditions in the estuary, impeding its full recovery. The results obtained in this study call for an evaluation of the ecosystem function in order to test if this partially restored system can be considered a functioning estuary even if the fish community has not completely reassembled.

\section{Acknowledgements}

Students from Instituto de Investigación en Ingeniería, Universidad Autónoma de Tamaulipas are greatly acknowledged for their field support. We acknowledge the commitment of Energía Iberdrola Altamira and Administración Portuaria Integral de Altamira in the restoration and protection of the Garrapatas estuary.

\section{REFERENCES}

[1] J. W. Day, C. A. S. Hall, W. M. Kemp, A. Yañez-Arancibia. Estuarine ecology, John Wiley and Sons, New York, 1989.

[2] R. Costanza, R. d'Arge, R. de Groot, S. Farber, M. Grasso, B. Hannon, K. Limburg, S. Naemm, R. V. O’Neill, J. Paruelo, R. G. Raskin, P. Sutton, M. van den Belt. The value of the world's ecosystem services and natural capital, Nature, Vol. 387, 253-260, 1997.

[3] J. Selleslagh, R. Amara. Environmental factors structuring fish composition and assemblages in a small macrotidal estuary (eastern English Channel), Estuarine, Coastal and Shelf Science, Vol. 79, 507-517 DOI:

10.1016/j.ecss.2008.05.006, 2008.

[4] M. Elliott, F. Dewailly. The structure and components of European estuarine fish assemblages, Netherlands Journal of Aquatic Ecology, Vol. 29, 397-417, 1995.

[5] A. K. Whitfield. Ichthyofaunal assemblages in estuaries: a South African case study, Reviews in Fish Biology and Fisheries, Vol. 9, 151-186, 1999.

[6] M. Castillo-Rivera, A. Kobelkowsky. Distribution and segregation of two sympatric Brevoortia species (Teleostei: Clupeidae), Estuarine, Coastal and Shelf Science, Vol. 50, 593-598 DOI 10.1006/ecss.1999.0588, 2000.

[7] M. W. Beck, K. L. Heck Jr., K. W. Able, D. L. Childers, D. B. Eggleston, B. M. Gillanders, B. Halpern, C. G. Hays, K. Hoshino, T. J. Minello, R. J. Orth, P. F. Sheridan, M. P. Weinstein. The identification, conservation, and management of estuarine and marine nurseries for fish and invertebrates, BioScience, Vol. 51, 633-641, 2001.

[8] I. Nagelkerken, S. Kleijnen, T. Klop, R. A. C. J. van der Brand, E. Cocheret de la Morinière, G. van der Velde. Dependence of Caribbean reef fishes on mangroves and seagrass beds as nursery habitats: a comparison of fish faunas between bays with and without mangroves/seagrass beds, Marine Ecology Progress Series, Vol. 214, 225-235, 2001. 
[9] J. Maes, M. Stevens, F. Ollevier. The composition and community structure of the ichthyofauna of the upper Scheldt Estuary: synthesis of a 10-year data collection (1991-2001), Journal of Applied Ichthyology, Vol. 21, 86-93, 2005.

[10] J. R. Chambers. Coastal degradation and fish population losses, in: R. S. Stroud (Ed.), Stemming the tide of coastal fish habitat loss, Proceedings of a Symposium on Conservation of Coastal Fish Habitat, Baltimore, 45-52, 1992.

[11] F. H. Sklar, J. A. Browder. Coastal environmental impacts brought about by alterations to freshwater flow in the Gulf of Mexico, Environmental Management, Vol. 22, 547-562, 1998.

[12] M. Alber. A conceptual model of estuarine freshwater inflow management, Estuaries, Vol. 25, No. 6B, 1246-1261, 2002.

[13] P. A. Montagna, M. Alber, P. Doering, M. S. Connor. Freshwater inflow: science, policy, management, Estuaries, Vol. 25, 1243-1245, 2002.

[14] P. M. Vitousek, H. A. Mooney, J. Lubchenco, J. M. Melillo. Human domination of Earth's ecosystems, Science, Vol. 277, 494-499, 1997.

[15] G. J. Edgar, N. S. Barrett, D. J. Graddon, P. R. Last. The conservation significance of estuaries: a classification of Tasmanian estuaries using ecological, physical and demographic attributes as a case study, Biological Conservation, Vol. 92, 383-397, 2000.

[16] C. E. Cintra Buenrostro, K. W. Flessa, D. L. Dettman. Restoration flows for the Colorado River estuary, Mexico: estimates from oxygen isotopes in the bivalve mollusk Mulinia coloradoensis (Mactridae: Bivalvia), Wetlands Ecology and Management, DOI 10.1007/s11273-012-9255-5, 2012.

[17] E. McCarron, R. Frydenborg. Using the human disturbance gradient to develop bioassessment procedures in estuaries, in: S. A. Bortone (Ed.), Estuarine indicators, C. R. C. Press, Boca Raton, 483-494, 2005.

[18] M. Shirley, P. O’Donnell, V. McGee, T. Jones. Nekton species composition as a biological indicator of altered freshwater inflow: a comparison of three south Florida estuaries, in: S. A. Bortone (Ed.), Estuarine indicators, C. R. C. Press, Boca Raton, 351-361, 2005.

[19] RAE, Restoring America's Estuaries, A national strategy to restore coastal and estuarine habitat, Online available from http://www.estuaries.org/a-national-strategy, 2002, Date Viewed December 19, 2014.

[20] A. Borja, S. B. Bricker, D. M. Dauer, N. T. Demetriades, J. G. Ferreira, A. T. Forbes, P. Hutchings, X. Jia, R. Kenchington, J. C. Marques, C. Zhu. Overview of integrative tools and methods in assessing ecological integrity in estuarine and coastal systems worldwide, Marine Pollution Bulletin, Vol. $56,1519-1537,2008$.

[21] L. Valderrama, C. Troche, M. T. Rodriguez, D. Marquez, B. Vázquez, S. Velázquez, A. Vázquez, M. I. Cruz, R. Ressl. Evaluation of mangrove cover changes in Mexico during the 1970-2005 period, Wetlands, Vol. 34, 747-758 DOI 10.1007/s13157-014-0539-9, 2014.

[22] M. A. Zaldivar-Jimenez, J. A. Herrera-Silveira, C. Teutli-Hernández, F. A. Comin, J. L. Andrade, C. Coronado Molina, P. Perez Ceballos. Conceptual framework for mangrove restoration in the Yucatan Peninsula, Ecological Restoration, Vol. 28, 333-342, 2010.

[23] M. A. Marquez, A. Fierro-Cabo, C. E. Cintra-Buenrostro. Can ecosystem functional recovery be traced to decomposition and nitrogen dynamics in estuaries of the Lower Laguna Madre, Texas? Restoration Ecology, DOI 10.1111/rec.12469, 2016.

[24] G. R. Gibson, M. L. Bowman, J. Gerritse, B. D. Snyder. Estuarine and coastal marine waters: bioassessment and biocriteria technical guidance, EPA 822-B-00-024, US Environmental Protection Agency Office of Water, Washington, D.C., 2000.

[25] J. C. Trexler, W. F. Loftus, S. Perry. Disturbance frequency and community structure in a twenty-five year intervention study, Oecologia, Vol. 145, 140-152 DOI: 10.1007/s00442-005-0094-4, 2005.

[26] M. Elliott, V. Quintino. The estuarine quality paradox, environmental homeostasis and the difficulty of detecting anthropogenic stress in naturally stressed areas, Marine Pollution Bulletin, Vol. 54, 640-645, 2007.

[27] W. B. Gladfelter, J. C. Ogden, E. H. Gladfelter. Similarity and diversity among coral reef fish communities: a comparison between tropical western Atlantic (Virgin Islands) and tropical central Pacific (Marshall Islands) patch reefs, Ecology, Vol. 61, 1156-1168, 1980.

[28] T. H. Fraser. Abundance, seasonality, community indices, trends and relationships with physicochemical factors of trawled fish in upper Charlotte Harbor, Florida, Bulletin of Marine Science, Vol. 60, 739-763, 1997.

[29] M. S. Peterson, S. T. Ross. Dynamics of littoral fishes and decapods along a coastal river-estuarine gradient, Estuarine, Coastal and Shelf Science, Vol. 33, 467-483, 1991.

[30] A. J. Jaureguizar, R. Menni, C. Bremec, H. Mianzan, C. Lasta. Fish assemblage and environmental patterns in the Río de la Plata Estuary, Estuarine, Coastal and Shelf Science, Vol. 56, 921-933 DOI 10.1016/S0272-7714(02)00288-3, 2003.

[31] S. Akin, E. Buhan, K. O. Winemiller, H. Yilmaz. Fish assemblage structure of Koycegiz Lagoon-Estuary, Turkey: spatial and temporal distribution patterns in relation to environmental variation, Estuarine, Coastal and Shelf Science, Vol. 64, 671-684 DOI 10.1016/j.ecss.2005.03.019, 2005.

[32] B. E. Luckhurst, K. Luckhurst. Diurnal space utilization in coral reef fish communities, Marine Biology, Vol. 49, 325-332, 1978 .

[33] P. F. Sale. Patterns of space use in a guild of territorial reef fishes, Marine Biology, Vol. 29, 89-97, 1975.

[34] J. P. Barry, M. M. Yoklavich, G. M. Cailliet, D. A. Ambrose, B. S. Antrim. Trophic ecology of the dominant fishes in Elkhorn Slough, California, 1974-1980, Estuaries, Vol. 19, 115-138, 1996.

[35] B. A. Menge, A. M. Olson. Role of scale and environmental factors in regulation of community structure, Trends in Ecology and Evolution, Vol. 5, 52-57, 1990.

[36] E. J. Martino, K. W. Able. Fish assemblages across the marine to low salinity transition zone of a temperate estuary, Estuarine, Coastal and Shelf Science, Vol. 56, 969-987 DOI 10.1016/S0272-7714(02)00305-0, 2003. 
[37] S. Jimenez Hernández, A. Fierro Cabo. Rescate ecológico del estuario del arroyo garrapatas, municipio de Altamira, Tamaulipas, Publicaciones de la SEMARNAT, Dirección General de Impacto y Riesgo Ambiental, Mexico, D.F., 2006.

[38] Google Earth, Online available from https://www.google.com/earth/, Date Viewed May 30, 2017.

[39] K. R. Clarke, R. N. Gorley. Primer v6: user manual/tutorial, Plymouth Marine Laboratory, Plymouth, 2006.

[40] K. R. Clarke, R. M. Warwick. Change in marine communities: an approach to statistical analysis and interpretation, Plymouth Marine Laboratory, $2^{\text {nd }}$ Ed., Plymouth, 2001.

[41] R. R. Sokal, F. J. Röhlf. Biometry, W. H. Freeman Company, $3^{\text {rd }}$ Ed., New York, 1995.

[42] J. H. Zar. Biostatistical analysis, Prentice Hall, $3^{\text {rd }}$ Ed., USA, 1996.

[43] I. Cardoso, M. P. Pais, S. Henriques, L. Cancela da Fonseca, H. N. Cabral. Ecological quality assessment of small estuaries from the Portuguese coast based on fish assemblages indices, Marine Pollution Bulletin, Vol. 62, 992-1001, 2012.

[44] A. Yañez-Arancibia, A. L. L. Dominguez, D. Pauly. Coastal lagoons as fish habitats, in: B. Kjerfve (Ed.), Coastal lagoon processes, Elsevier Science Publishers, Amsterdam, 363-376, 1994.

[45] S. R. Connolly, T. P. Hughes, D. R. Bellwood, R. H. Karlson. Community structure of corals and reef fishes at multiple scales, Science, Vol. 309, 1363-1365, 2005.
[46] R. M. Hughes, P. R. Kaufmann, A. T. Herlihy, T. M. Kincaid, L. Reynolds, D. P. Larsen. A process for developing and evaluating indices of fish assemblage integrity, Canadian Journal of Fisheries and Aquatic Sciences, Vol. 55, 1618-1631, 1998.

[47] I. R. Waite, K. D. Carpenter. Associations among fish assemblage structure and environmental variables in Willamette Basin Streams, Oregon, Transactions of the American Fisheries Society, Vol. 129, 754-770, 2000.

[48] F. H. McCormick, D. V. Peck, D. P. Larsen. Comparison of geographic classification schemes for Mid-Atlantic stream fish assemblages, Journal of the North American Benthological Society, Vol. 19, 385-404, 2000.

[49] S. R. Floeter, W. Krohling, J. L. Gasparini, C. E. L. Ferreira, I. R. Zalmon. Reef fish community structure on coastal islands of the southeastern Brazil: the influence of exposure and benthic cover, Environmental Biology of Fishes, Vol. 78, 147-160 DOI 10.1007/s10641-006-9084-6, 2007.

[50] L. Cardona. Effects of salinity on the habitat selection and growth performance of Mediterranean Flathead Grey Mullet Mugil cephalus (Osteichthyes, Mugilidae), Estuarine, Coastal and Shelf Science, Vol. 50, 727-737 DOI: 10.1006/ecss. 1999.0594, 2000

[51] R. Thiel, A. Sepúlveda, R. Kafemann, W. Nellen. Environmental factors as forces structuring the fish community of the Elbe Estuary, Journal of Fish Biology, Vol. 46, 47-69, 1995.

[52] A. K. Whitfield, A. W. Paterson, A. H. Bok, H. M. Kok. A comparison of the ichthyofaunas in two permanently open Eastern Cape estuaries, South African Journal of Zoology, Vol. 29, 175-185, 1994. 